Article

\title{
Bioguided Purification of Active Compounds from Leaves of Anadenanthera colubrina var. cebil (Griseb.) Altschul
}

\author{
Daniel Rodrigo Cavalcante de Araújo ${ }^{1,2, *}$, Túlio Diego da Silva ${ }^{3}$, Wolfgang Harand ${ }^{1}$, \\ Claudia Sampaio de Andrade Lima ${ }^{4}$, João Paulo Ferreira Neto ${ }^{4}$, \\ Bárbara de Azevedo Ramos ${ }^{2}$ (D), Tamiris Alves Rocha ${ }^{2}$, Harley da Silva Alves 5 (D), \\ Rayane Sobrinho de Sousa ${ }^{6}$, Ana Paula de Oliveira ${ }^{7}$, Luís Cláudio Nascimento da Silva ${ }^{6, *(D),}$ \\ Jackson Roberto Guedes da Silva Almeida ${ }^{7}$ (D), Márcia Vanusa da Silva ${ }^{2}$ and \\ Maria Tereza dos Santos Correia ${ }^{2}$ \\ 1 Instituto Nacional do Semiárido (INSA/MCTIC), 58429-500 Campina Grande, Brazil; \\ wolfgang.harand@insa.gov.br \\ 2 Departamento de Bioquímica, Centro de Biociências, Universidade Federal de Pernambuco (UFPE), \\ 50670-901 Recife, Brazil; babi.a.ramos@gmail.com (B.d.A.R.); tamialvesinsl@gmail.com (T.A.R.); \\ marciavanusa@yahoo.com.br (M.V.d.S.); mtscorreia@gmail.com (M.T.d.S.C.) \\ 3 Centro de Tecnologias Estratégicas do Nordeste (CETENE/MCTIC), 50670-901 Recife, Brazil; \\ tulio.silva@cetene.gov.br \\ 4 Departamento de Biofísica e Radiobiologia, Centro de Biociências, Universidade Federal de \\ Pernambuco (UFPE), 50670-901 Recife, Brazil; claudia.salima@gmail.com (C.S.d.A.L.); \\ joaopaulo.ferreiraneto@gmail.com (J.P.F.N.) \\ 5 Laboratório de Fitoquímica, Departamento de Farmácia e Pós-graduação em Ciências Farmacêuticas, \\ Universidade Estadual da Paraíba (UEPB), 58429-500 Campina Grande, Brazil; harley.alves@hotmail.com \\ 6 Laboratório de Patogenicidade Microbiana, Universidade CEUMA, 65080-805 São Luís, Brazil; \\ rayane_sobrinho@hotmail.com \\ 7 Central de Análise de Fármacos, Medicamentos e Alimentos, Universidade Federal do Vale do São \\ Francisco (CAFMA/UNIVASF), 56328-903 Petrolina, Brazil; ana_tecquimica@yahoo.com.br (A.P.d.O.); \\ jackson.guedes@univasf.edu.br (J.R.G.d.S.A.) \\ * Correspondence: daniel.araujo@insa.gov.br (D.R.C.d.A.); luiscn.silva@ceuma.br (L.C.N.d.S.)
}

Received: 27 August 2019; Accepted: 25 September 2019; Published: 8 October 2019

\begin{abstract}
Anadenanthera colubrina var cebil (Griseb.) Altschul is a medicinal plant found throughout the Brazilian semi-arid area. This work performed a bioguided purification of active substances present in ethyl acetate extract from A. colubrina leaves. The anti-Staphylococcus aureus and antioxidant actions were used as markers of bioactivity. The extract was subjected to flash chromatography resulting in five fractions (F1, F2, F3, F4, and F5). The fractions F2 and F4 presented the highest antimicrobial action, with a dose able to inhibit $50 \%$ of bacteria growth (IN50) of $19.53 \mu \mathrm{g} / \mathrm{mL}$ for S. aureus UFPEDA 02; whereas F4 showed higher inhibitory action towards DPPH radical (2,2-diphenyl-1-picryl-hydrazyl-hydrate) [dose able to inhibit $50 \%$ of the radical $($ IC50) $=133 \pm 9 \mu \mathrm{g} / \mathrm{mL}] . \quad F 2$ and F4 were then subjected to preparative high-performance liquid chromatography (HPLC) and nuclear magnetic resonance (NMR), resulting in the identification of $p$-hydroxybenzoic acid and hyperoside as the major compounds in F2 and F4, respectively. Hyperoside and $p$-hydroxybenzoic acid presented IN50 values of $250 \mu \mathrm{g} / \mathrm{mL}$ and $500 \mu \mathrm{g} / \mathrm{mL}$ against $S$. aureus UFPEDA 02 , respectively. However, the hyperoside had an IN50 of $62.5 \mu \mathrm{g} / \mathrm{mL}$ against $S$. aureus UFPEDA 705, a clinical isolate with multidrug resistant phenotype. Among the purified compounds, the proanthocyanidins obtained from F2 exhibited the higher antioxidant potentials. Taken together, these results highlight the potential of $A$. colubrina leaves as an alternative source of biomolecules of interest for the pharmaceutical, food, and cosmetic industries.
\end{abstract}


Keywords: Staphylococcus aureus; medicinal plant; compound purification

\section{Introduction}

The World Health Organization (WHO), in its document "Strategies on Traditional Medicine", promotes the strengthening of quality assurance, safety, and proper use of medicinal plants. This document suggests the regulation of products and practices associated with medicinal plants [1]. This is important since the products derived from medicinal plants may not contain the active ingredient in adequate quantity due the environmental influences, absence of nutrients in the soil [2]. Other issues comprise chemical and microbial (or their toxins) contamination $[3,4]$. These failures contribute to the lack of confidence of medical professionals in prescribing their patients medicinal plants [5]. In this sense, although the population uses several products derived from plants (such as teas and tinctures), due to their therapeutic properties, the obtaining of purified compounds for high-precision identification is still necessary to characterize their composition [6,7]. For this, it is necessary to use organic solvents in extractive and chromatographic techniques that can be accompanied by chemical or biological tests, aiming at the isolation of the active compounds $[8,9]$.

Anadenanthera colubrina var cebil (Griseb). Altschul is a plant from Fabaceae family that occurs in countries such as Brazil and Argentina [10,11]. A. colubrina stands out due its medicinal properties, which include the application of different tissues for treatment of inflammatory disorders [12,13]. In particular, A. colubrina is pointed as one of the most important medicinal plant of Caatinga area (the Brazilian semi-arid ecosystem), where it is popularly known as angico [14,15]. Several scientific studies have evidenced the pharmacological properties of products derived from A. colubrina (mostly extracts and fractions) that include antimicrobial [11,16,17], antioxidant [18-21], wound-healing [22,23], anti-inflammatory [24,25], antinociceptive [20,25], and antiproliferative actions [19,26]. Despite this therapeutic potential, little information is available about the chemical identity of the active(s) compound(s) responsible for each action. Therefore, the present work aimed to perform a bioguided study to obtain compounds from A. colubrina var cebil with antimicrobial and antioxidant activities.

\section{Materials and Methods}

\subsection{Collection and Identification of the Specie Anadenanthera Colubrina Var Cebil}

The aerial parts of A. colubrina var cebil were collected near to the area known as Pedra do Cachorro in the Catimbau Valley National Park (Buíque, Pernambuco, Brazil; the approximate coordinates are: $08^{\circ} 34^{\prime} 30.96^{\prime \prime} \mathrm{S}$ and $37^{\circ} 14^{\prime} 51.76^{\prime \prime} \mathrm{O}$ ). The collection was performed in March 2015 . The authors confirm that the authority designated Chico Mendes Institute for Biodiversity Conservation (ICMbio) granted permission through the System of Authorization and Information on Biodiversity (SISBIO) with authentication code $n^{\circ} 86962334$. Exsiccates were prepared and the specimen was incorporated into the Dárdano de Andrade Lima herbarium of the Agronomic Institute of Pernambuco (IPA-PE; voucher protocol $n^{\circ} 80351$ ).

\subsection{Preparation of Extracts}

The aerial parts were oven-dried at $45{ }^{\circ} \mathrm{C}$ (Marconi MA 035/511, Marconi Equipamentos Ltda, São Paulo, Brazil) for 3 days, and then ground in an industrial Blender (Skymsen Inox LB-25MB, Metalúrgica Skymsen Ltda, Santa Catarina, Brazil) until a powder was obtained. The powder was sieved (Mesh 35 and 14) and subjected to the Accelerated Solvent Extractor (ASE 350 Fisher Scientific, Pittsburgh, PA, USA) In the extractor, six extraction cells containing $20 \mathrm{~g}$ of the powder were subjected to extractions following the eluotropic series (hexane, ethyl acetate, and methanol). Each solvent was used for $45 \mathrm{~min}$ with a flow rate of $5 \mathrm{~mL} / \mathrm{min}$ at $40{ }^{\circ} \mathrm{C}$ under a pressure of $\pm 1500 \mathrm{psi}$. After this procedure, were obtained the hexane extract (ASE-Hex; $2.9 \%$ yield), ethyl acetate extract (ASE-AcOEt; 
$4.5 \%$ ), and methanol extract (ASE-MeOH with 22.5\%). The extract previously filtered in ASE 350 was concentrated in Rocket Evaporator (Fisher Scientific, Pittsburgh, PA, USA) at $40^{\circ} \mathrm{C}$.

\subsection{Phytochemical Analysis and Purification}

\subsubsection{Flash Chromatography}

The ASE-AcOEt extract was submitted for fractionation using flash chromatography (Biotage Isolera one, Biotage company, Charlotte, NC, USA). The separation occurred on the SNAP KP-SIL (Biotage company, Charlotte, NC, USA) 50 g column through a mobile phase with a gradient of toluene:ethyl acetate (PhME: AcOEt, 20:70) with 1 column volume (1 CV), followed by $100 \%$ AcOEt $(6 \mathrm{CV})$ and then for AcOEt: 70:20 MeOH $(6 \mathrm{CV})$ with flow rate of $70 \mathrm{~mL} / \mathrm{min}$ and scanning detection of 200-800 $\mathrm{nm}$. The fractions were grouped by software that suggested the fractions according to the UV absorption spectrum, and thus five fractions were grouped: F1, F2, F3, F4, and F5.

\subsubsection{High-Performance Liquid Chromatography (HPLC-DAD)}

The extracts, fractions, and isolated compounds were analyzed by HPLC (1260 infinity LC System-DAD, Agilent OpenLAB CDS EZChrom Edition software, version 04.05 of Agilent Technologies, Santa Clara, CA, USA). The samples were prepared to obtain a concentration of $5 \mathrm{mg} / \mathrm{mL}$ and were sonicated until complete solubilization. They were filtered with $0.22 \mu \mathrm{m}$ PTFE filters and then analyzed by HPLC. The compounds separation occurred via the column: Zorbax, SB-C18, $5 \mu \mathrm{m}$ and $4.6 \times 250 \mathrm{~mm}$ with $5 \mu \mathrm{m}$ Zorbax SB-C18 pre-column and $4.6 \times 12.5 \mathrm{~mm}$. The solvents used were: Mili-Q water (Millipore, Burlington, MA, USA) with $0.3 \%$ acetic acid (A) and acetonitrile (B) (LiChrosolv, Merck, Darmstadt, Hessen, Germany) following a linear gradient of $92-65 \%$ (A) 0-15 min; the initial conditions returning $65-92 \%(\mathrm{~A})$, then at $40{ }^{\circ} \mathrm{C}$, flow rate $2.4 \mathrm{~mL} / \mathrm{min}$, initial pressure $210 \mathrm{bar}$, and scanning detection at 190-400 $\mathrm{nm}$. This method was accomplished after an exploratory method of $60 \mathrm{~min}$ and flow of $1 \mathrm{~mL} / \mathrm{min}$ and was considered as satisfactory for analyses of the samples' contents and for the standards gallic acid, $p$-coumaric acid, caffeic acid, catechin, ferulic acid, luteolin, isoquercetin, chlorogenic acid, quercetin, rutin, ellagic acid, and geraniin.

\subsubsection{Preparative High-Performance Liquid Chromatography Coupled To Mass} Spectrometry (HPLC-MS)

The fractions F2 and F3 from the flash chromatography system were analyzed using the preparative HPLC (Waters autopurification system, Milford, MA, USA) with fraction collector, UV detector 2489, and ACQUITY QDa. The fractions were dissolved in $\mathrm{MeOH}$ and filtered with $0.22 \mu \mathrm{m}$ PTFE filters until several samples with a final value of $15 \mathrm{mg} / \mathrm{mL}$ were obtained. The separation and isolation of the compounds occurred via the preparative column XBridge Prep C18 $(5 \mu \mathrm{m}$ and $10 \times 100 \mathrm{~mm})$, by means of the following mobile phase; Mili-Q water with $0.1 \%$ formic acid (A) and acetonitrile (B) (LiChrosolv, Merck, Darmstadt, Hessen, Germany) with linear gradient 94-65\% (A) 0-9 min; the initial conditions were then returned to room temperature, flow rate of $9 \mathrm{~mL} / \mathrm{min}$, and detection at $256 \mathrm{~nm}$; only the main and unknown constituents were collected.

\subsubsection{Ultra-High-Performance Liquid Chromatography Coupled to Mass Spectrometry (UPLC-MS)}

The ASE-AcOEt extract was analyzed in AQUITY H-Class (Milford, MA, USA) on a BEH $2.1 \times 100 \mathrm{~mm}, 1.7 \mu \mathrm{m}$ column. The mobile phase consisted of aqueous solution containing $2 \% \mathrm{MeOH}$, $5 \mathrm{mM}$ ammonium formate and $0.1 \%$ formic acid (A) and methanolic solution containing $0.1 \%$ formic acid (B), which were pumped into a flow rate of $0.3 \mathrm{~mL} / \mathrm{min}$, and $10 \mu \mathrm{L}$ of the sample were injected. The elution was performed in gradient mode and the initial condition $98 \%$ of the eluent $A$ was maintained for $15 \mathrm{~s}$. The proportion of the phase B was linearly increased to $99 \%$ in $8.5 \mathrm{~min}$, remaining at $99 \%$ for $1 \mathrm{~min}$, then returning to the initial conditions of analyses. The column oven was maintained at $40{ }^{\circ} \mathrm{C}$. The data acquisition was done in the full-scan mode, searching for masses between 100 and $1000 \mathrm{Da}$, 
in negative ionization. The acquisition of the chromatograms and mass spectra was done through MassLynx software.

\subsubsection{Nuclear Magnetic Resonance (NMR)}

The compounds isolated by preparative HPLC-MS were analyzed by NMR. 1D-NMR $\left({ }^{1} \mathrm{H}\right.$ and ${ }^{13} \mathrm{C}$ $(1 \mathrm{H})$ ) and $2 \mathrm{D}\left({ }^{1} \mathrm{H}-{ }^{1} \mathrm{H}\right.$ COSY, ${ }^{1} \mathrm{H}-{ }^{13} \mathrm{C}$ HSQC , and $\left.{ }^{1} \mathrm{H}_{-}{ }^{13} \mathrm{C} \mathrm{HMBC}\right)$ were acquired at $23{ }^{\circ} \mathrm{C}$ in deuterated dimethyl sulfoxide (DMSO-d ${ }^{6}$ ) in a Bruker ASCEND III 400 a 9.4 T (Billerica, MA, USA), observing ${ }^{1} \mathrm{H}$ and ${ }^{13} \mathrm{C}$ at 400 and $100 \mathrm{MHz}$, respectively. The NMR spectrometer was equipped with a $5 \mathrm{~mm}$ multinuclear direct detection probe (BBO probe) with gradient $\mathrm{z}$. The correlation experiments of ${ }^{1} \mathrm{H}_{-}{ }^{13} \mathrm{C}$ one-link (HSQC) and long-range (HMBC) were optimized for the mean coupling constant $1 \mathrm{~J}$ $(\mathrm{C}, \mathrm{H})$ and LRJ $(\mathrm{C}, \mathrm{H})$ of 140 and $8 \mathrm{~Hz}$, respectively. All ${ }^{1} \mathrm{H}$ and ${ }^{13} \mathrm{C}-\mathrm{NMR}(\delta) \mathrm{NMR}$ chemical shifts are given in ppm relative to the TMS signal at $0.00 \mathrm{ppm}$ as an internal reference, and the coupling constants (J) in $\mathrm{Hz}$.

\subsection{Antimicrobial Activity}

\subsubsection{Microbial Strains}

The antimicrobial assay was performed with Staphylococcus aureus UFPEDA 02 (=ATCC 6538) and S. aureus UFPEDA 705, both provided by the Culture Collection of the Department of Antibiotics from Federal University of Pernambuco (UFPEDA). S. aureus UFPEDA 705 is a methicillin-resistant isolate (Methicillin-Resistant S. aureus (MRSA)) obtained from surgical wound, and resistant to diverse antibiotics, including drugs from the beta-lactam group (e.g., ampicillin, oxacillin, cephalothin, cefoxitin, cefepime, and cefuroxime), nalidixic acid, nitrofurantoin, and gentamicin [27].

\subsubsection{Antimicrobial Assay}

The antimicrobial action was performed using a broth microdilution assay based on the detection of bacterial growth by spectrophotometric measurement, as proposed by Quave et al. [28]. The ASE-AcOEt extract, fractions (F1, F2, F3, F4, and F5) and the compounds (hyperoside, $p$-hydroxybenzoic acid and proanthocyanidins) were dissolved in 10\% aqueous solution of DMSO until a homogeneous mixture was obtained ( $5000 \mu \mathrm{g} / \mathrm{mL}$ for extract and fraction; $1000 \mu \mathrm{g} / \mathrm{mL}$ for isolated compounds). In a 96-well microplate, serial dilutions of each sample were prepared in Muller-Hilton Broth (MHB). The concentrations tested for ASE-AcOEt extract and its fractions (F1, F2, F3, F4, and F5) ranged from 2500 to $9.76 \mu \mathrm{g} / \mathrm{mL}$; whereas purified compounds were tested from $500 \mu \mathrm{g} / \mathrm{mL}$ to $1.9 \mu \mathrm{g} / \mathrm{mL}$. Following, each well received $20 \mu \mathrm{L}$ of bacterial suspension (approximately $1.5 \times 10^{8} \mathrm{CFU} / \mathrm{mL}$ ). Untreated bacteria and vehicle-treated bacteria were used as positive controls of microbial growth. The plates were read in a spectrophotometer at $600 \mathrm{~nm}$ after the serial dilution (T0h) and after $24 \mathrm{~h}$ (T24h) of oven conditioning at $37^{\circ} \mathrm{C}$. Subsequently, the IN50 (concentration able to inhibit 50\% of bacterial growth), was calculated according to the equation below [28].

$$
\text { Equation: \% inhibition }=[1-(\text { ODT24h }- \text { ODT0h }) /(\text { ODgc } 24 h-\text { ODgc0h })] \times 100
$$

where ODT24h $=$ optical density $(600 \mathrm{~nm})$ of the test plate at $24 \mathrm{~h}$ of inoculation; ODT0h $=$ optical density $(600 \mathrm{~nm})$ of the test plate shortly after inoculation; ODgc $24 \mathrm{~h}=$ optical density $(600 \mathrm{~nm})$ of the bacterial growth control wells after $24 \mathrm{~h}$ of inoculation; and ODgc0h = optical density $(600 \mathrm{~nm})$ of the bacterial growth control wells shortly after inoculation. 


\subsection{Antioxidant Activity}

\subsubsection{Free Radical Sequestration}

In this assay, the free radical scavenging activity of each sample (ASE-AcOEt extract, fractions (F1, F2, F3, F4, and F5), and the compounds (hyperoside, $p$-hydroxybenzoic acid, and proanthocyanidins)) was measured in terms of hydrogen donation using 2,2-diphenyl-1-picrihydrazyl radical (DPPH) [29]. An aliquot of $250 \mu \mathrm{L}$ of DPPH methanolic solution (with absorbance of 0.7 at $517 \mathrm{~nm}$ ) was mixed with $40 \mu \mathrm{L}$ of different sample concentrations which were previously dissolved in methanol $(31.25,62.5,125$, 500 , and $1000 \mu \mathrm{g} / \mathrm{mL}$ ). After $25 \mathrm{~min}$, the absorbance at $517 \mathrm{~nm}$ was measured. Gallic acid was used as the reference compound and the negative control was the DPPH solution added to $40 \mu \mathrm{L}$ of methanol. The elimination of DPPH radicals was calculated by the formula

$$
\text { Inhibition of DPPH }(\%)=[(\mathrm{Aa}-\mathrm{Ac}) / \mathrm{Ac}] \times 100
$$

where Aa is absorbance of the sample and Ac is control absorbance. The concentration that inhibited $50 \%$ (IC50) of DPPH radical was calculated by linear regression.

\subsubsection{Total Antioxidant Activity (TAA)}

The purified compounds (hyperoside, $p$-hydroxybencoic acid, and proanthocyanidins) were dissolved to the concentration of $1 \mathrm{mg} / \mathrm{mL}$ in methanol, and $0.1 \mathrm{~mL}$ of each sample was mixed with $1 \mathrm{~mL}$ of the phosphomolybdenum solution $(600 \mathrm{mM}$ sulfuric acid, $28 \mathrm{mM}$ sodium phosphate, and $4 \mathrm{mM}$ ammonium molybdate), and then incubate in water at $95{ }^{\circ} \mathrm{C}$ for $90 \mathrm{~min}$. After returning to room temperature, the absorbance of each samples were measured at $695 \mathrm{~nm}$ against a blank $(1 \mathrm{~mL}$ of solution and $0.1 \mathrm{~mL}$ of methanol) [30]. The total antioxidant activity was expressed in relation to ascorbic acid and calculated by the formula

$$
\operatorname{TAA}(\%)=[(\mathrm{Aa}-\mathrm{Ac}) /(\mathrm{Aaa}-\mathrm{Ac})] \times 100
$$

where Ac is control absorbance, Aa is sample absorbance, and Aaa is absorbance of ascorbic acid.

\subsubsection{Reduction of Ferric ion (FRAP Method)}

The FRAP assay was performed with the compounds: hyperoside, $p$-hydroxybenzoic acid, and purified proanthocyanidins. The assay was done according to Benzie et al. [31] with modifications. The FRAP reagent was freshly prepared by mixing stock solution of $300 \mathrm{mM}$ acetate buffer $(\mathrm{pH} 3.6)$, $10 \mathrm{mM}$ 2,4,6-tripyridyl-s-triazine (TPTZ) (solubilized in $40 \mathrm{mM} \mathrm{HCl}$ ), and $20 \mathrm{mM} \mathrm{FeCl}_{3}$ in a proportion 1:1:10 $(v / v / v)$. Samples of $0.07 \mathrm{~mL}$ of the purified compounds were used in a concentration of $1 \mathrm{mg} / \mathrm{mL}$ and mixed with $0.2 \mathrm{~mL}$ of the FRAP reagent and allowed to stand for $30 \mathrm{~min}$ at $37^{\circ} \mathrm{C}$ in the dark. Subsequently the samples were read at $593 \mathrm{~nm}$. A standard curve was made with $\mathrm{FeSO}_{4}(0-1000 \mu \mathrm{g} / \mathrm{mL})$ $\left(y=0.0054 x+0.1465\right.$ and $\left.R^{2}=0.9874\right)$. The results are expressed in $\mu \mathrm{g} \mathrm{FeSO}_{4}(\mathrm{II}) / \mathrm{mg}$ and compared with gallic acid under the same conditions.

\subsection{Statistical Analysis}

All assays were performed in triplicate in at least two independent experiments. The results were expressed as mean and standard deviation. The data were submitted to analysis of variance (ANOVA) and for comparisons between the means the Tukey test was used through the software' Past version 2.17. The differences were considered statistically significant when $p<0.05$. 


\section{Results}

\subsection{Purification of Compounds from Anadenanthera Colubrina}

The qualitative analysis by HPLC-DAD of ASE-AcOEt extract indicated the presence of quercetin and low levels of catechin, $p$-coumaric acid and gallic acid. The acquisition of the 3D chromatogram with scanning from 190 to $400 \mathrm{~nm}$ (Figure 1) pointed the presence of approximately 10 compounds with absorption greater than $200 \mathrm{mAU}$. Among the major compounds, specifically between the retention times (Rt) 4 and $6 \mathrm{~min}$, is $p$-hydroxybencoic acid $(m / z$ of $137[\mathrm{M}+\mathrm{H}])$, which was purified by preparative HPLC and identified by NMR. Between the retention times of 8 and $10 \mathrm{~min}$, two signals with UV spectra characteristic of quercetin derivatives were detected (Figure 1). One of them was the hyperoside compound $\left(m / z\right.$ of $\left.487[\mathrm{M}+\mathrm{Na}]^{+}\right)$, which was also purified and identified as previously described. This is the first report of purification and identification of hyperoside in aerial parts of $A$. colubrina, this compound represents approximately $15 \%$ of the whole sample. At the retention times of 10 and 12 min, two proanthocyanidins $(m / z$ of $530[\mathrm{M}])$ were identified based on analyzes of mass spectrometry.

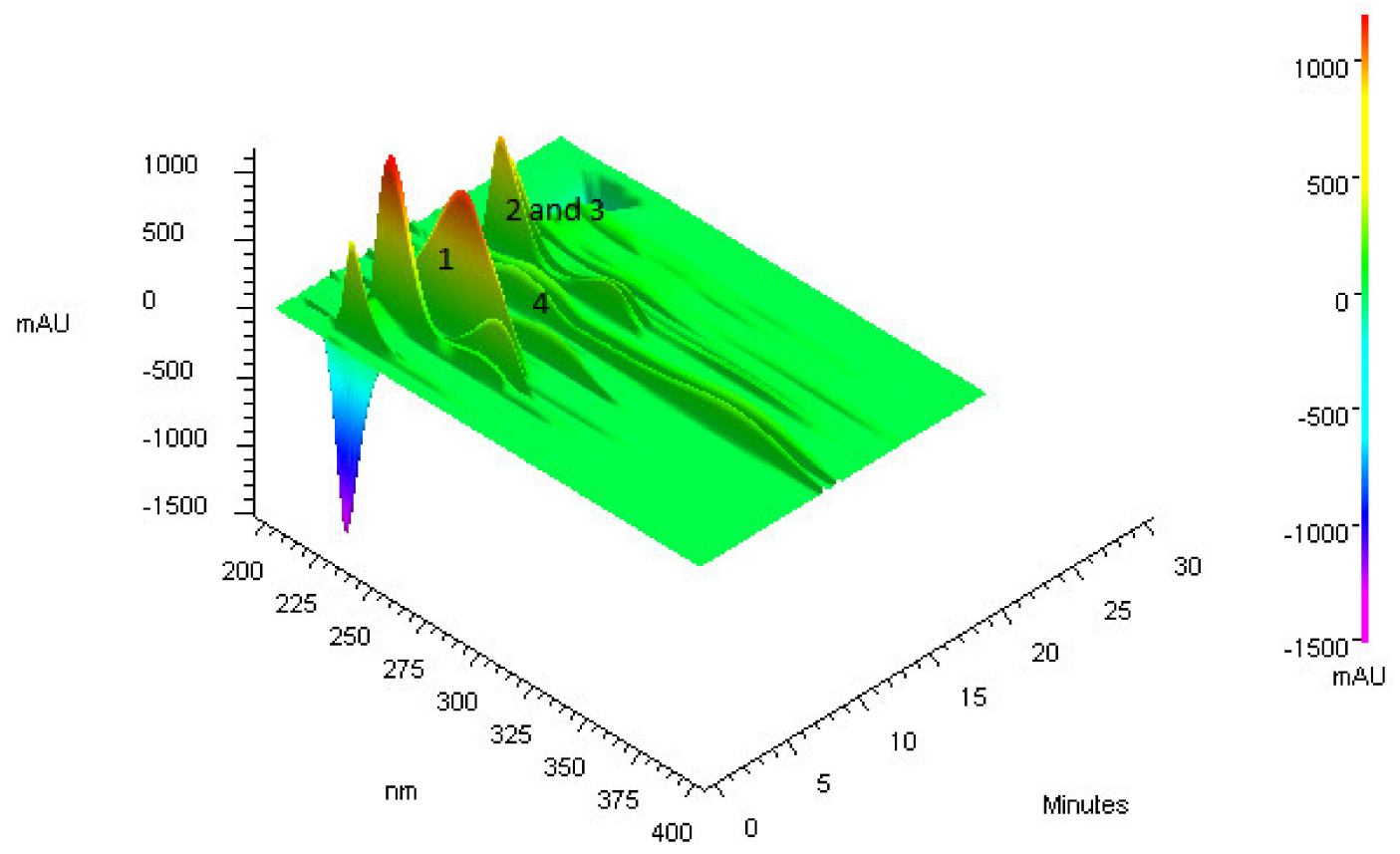

Figure 1. 3D chromatogram of an exploratory analysis of the ASE-AcOEt extract. In the image we can see approximately 10 major compounds. Compound $1\left(\lambda \max 255\right.$ and $\left.\mathrm{m} / z 137[\mathrm{M}+\mathrm{H}]^{-}\right)$is p-hydroxybenzoic acid; compound 2 ( $\lambda \max 280)$ and compound 3 are ( $\lambda \max 281)$ proanthocyanidins; and compound 4 is $\left(\lambda \max 256\right.$ and 355 and $\left.m / z 487[\mathrm{M}+\mathrm{Na}]^{+}\right)$hyperoside.

\subsection{Bioguided Purification of Compounds from Anadenanthera Colubrina}

The ASE-AcOEt extract had IN50 values of $312.5 \mu \mathrm{g} / \mathrm{mL}$ and $2500 \mu \mathrm{g} / \mathrm{mL}$ against $S$. aureus UFPEDA 02 and $S$. aureus UFPEDA 705, respectively. In relation to antioxidant activity, the extract showed an IC50 $142 \pm 10 \mu \mathrm{g} / \mathrm{mL}$ in DPPH assay. This extract was submitted to flash chromatography, which generated 35 fractions that were grouped according to the UV absorption profile in five groups: F1, F2, F3, F4, and F5 with yields of 7, 16, 16, 42, and 7.6\%, respectively (Figure 2). The fractions F2 and F4 were the most promising as antioxidants (IC50 of $202 \pm 6 \mu \mathrm{g} / \mathrm{mL}$ and $133 \pm 9 \mu \mathrm{g} / \mathrm{mL}$ in DPPH assay, respectively) and antimicrobials agents (IN50 of $19.53 \mu \mathrm{g} / \mathrm{mL}$ for both samples towards $S$. aureus UFPEDA 02) (Table 1). These two fractions proceeded to the preparative HPLC system.

The major compound in F2 had maximum absorption at $255 \mathrm{~nm}$ and it was isolated with high purity and identified by NMR as $p$-hydroxybencoic acid (1) (Figure 2). In the same fraction, two compounds that appeared to be proanthocyanidins (2 and 3) $(531.44 \mathrm{~m} / \mathrm{z} \mathrm{ES}+$ ) were also isolated. 
Compounds derived from quercetin were detected in high levels in $\mathrm{F} 4$, being one of them identified as hyperoside (4) (Figure 2). These results were confirmed by UPLC-MS.
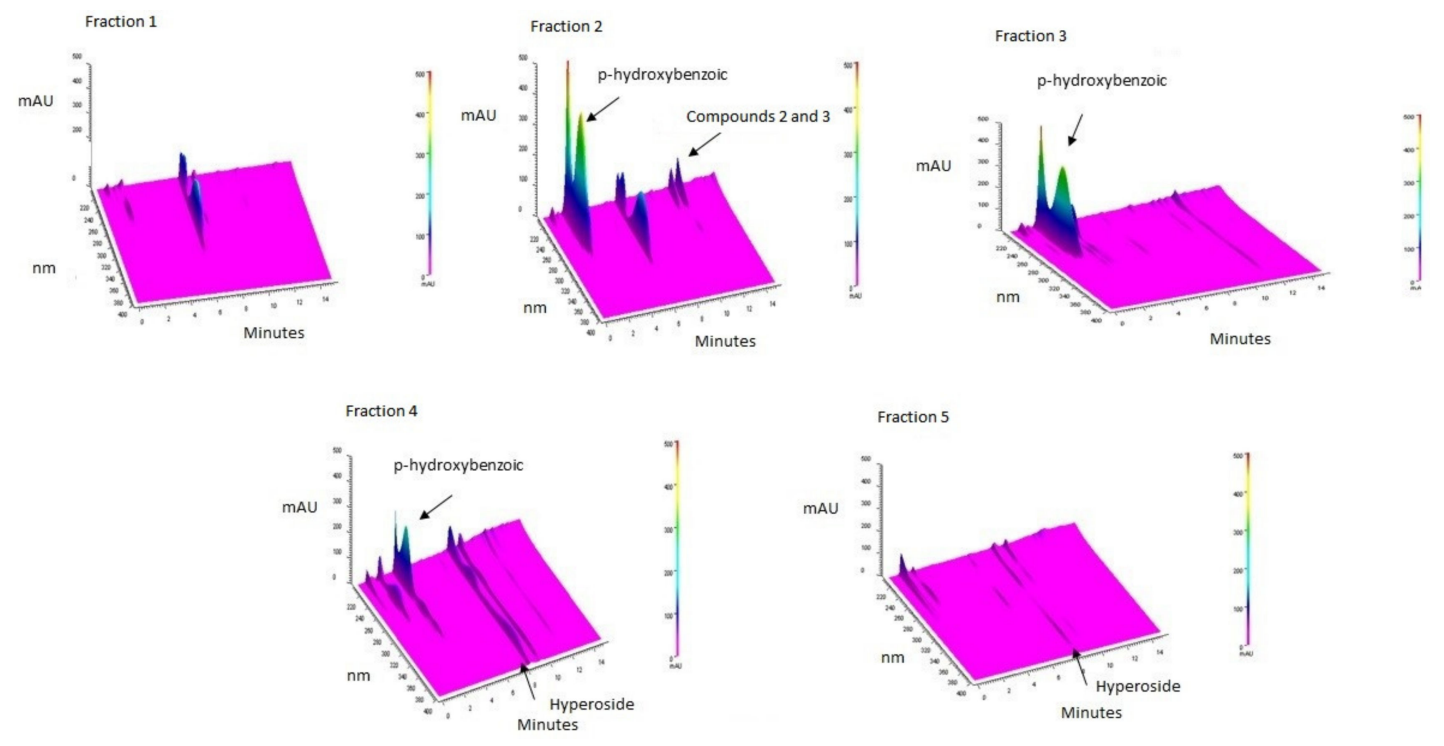

Figure 2. 3D chromatogram of fractions F1, F2, F3, F4, and F5. The chromatogram 3D allows visualizing the compounds by means of their respective UV spectra (1: $p$-hydroxybenzoic acid, 2 and $\mathbf{3}$ : proanthocyanidins and 4: hyperoside), their position in the chromatogram with respect to time on a scale of 190 to $400 \mathrm{~nm}$. mAU: Signal strength; nm: wavelength; t: time.

Table 1. Antimicrobial and antioxidant assay of the extract, fractions and compounds isolated from Anadenanthera colubrina var cebil.

\begin{tabular}{|c|c|c|c|c|c|}
\hline \multirow{3}{*}{ Samples } & \multirow{2}{*}{\multicolumn{2}{|c|}{$\begin{array}{c}\text { Antimicrobial Activity } \\
\text { IN50 }(\mu \mathrm{g} / \mathrm{mL})\end{array}$}} & \multicolumn{3}{|c|}{ Antioxidant Activity } \\
\hline & & & \multirow{2}{*}{$\begin{array}{c}\text { DPPH } \\
\mathrm{IC} 50(\mu \mathrm{g} / \mathrm{mL})\end{array}$} & \multirow{2}{*}{$\begin{array}{c}\text { TAA } \\
\%\end{array}$} & \multirow{2}{*}{$\frac{\text { FRAP }}{\mu \mathrm{g} \mathrm{FeSO} / \mathrm{mg}}$} \\
\hline & $\begin{array}{c}\text { S. aureus } \\
\text { UFPEDA } 02\end{array}$ & $\begin{array}{c}\text { S. aureus } \\
\text { UFPEDA } 705\end{array}$ & & & \\
\hline ASE-AcOEt & 312.5 & 2500 & $142 \pm 10$ & $\mathrm{~N} / \mathrm{E}$ & $\mathrm{N} / \mathrm{E}$ \\
\hline Fraction $1(\mathrm{~F} 1)$ & 2500 & 2500 & N/A & $\mathrm{N} / \mathrm{E}$ & $\mathrm{N} / \mathrm{E}$ \\
\hline Fraction 2 (F2) & 19.53 & 2500 & $202 \pm 6^{a}$ & $\mathrm{~N} / \mathrm{E}$ & $\mathrm{N} / \mathrm{E}$ \\
\hline Fraction 3 (F3) & 78.12 & $>2500$ & $263 \pm 17^{b}$ & $\mathrm{~N} / \mathrm{E}$ & $\mathrm{N} / \mathrm{E}$ \\
\hline Fraction 4 (F4) & 19.53 & $>2500$ & $133 \pm 9^{c}$ & $\mathrm{~N} / \mathrm{E}$ & $\mathrm{N} / \mathrm{E}$ \\
\hline Fraction 5 (F5) & $>2500$ & $>2500$ & $218 \pm 7.6^{\mathrm{a}}$ & $\mathrm{N} / \mathrm{E}$ & $\mathrm{N} / \mathrm{E}$ \\
\hline$p$-hydroxybenzoic acid (1) & 500 & $>500$ & N/A & $\mathrm{N} / \mathrm{E}$ & $\mathrm{N} / \mathrm{E}$ \\
\hline Proanthocyanidin (2) & 500 & $>500$ & $124.8 \pm 7^{c}$ & $60 \pm 3.3^{\mathrm{a}}$ & $550.22 \pm 10.43$ \\
\hline Proanthocyanidin (3) & 62.5 & $>500$ & $178.4 \pm 5^{\mathrm{a}}$ & $35 \pm 0.67^{b}$ & $552.62 \pm 5.23$ \\
\hline Hyperoside (4) & 250 & 62.5 & $258 \pm 20^{b}$ & $4.31 \pm 0.81^{\mathrm{c}}$ & $529.91 \pm 21.55$ \\
\hline Ampicillin & $<1.9$ & 3.9 & $\mathrm{~N} / \mathrm{E}$ & $\mathrm{N} / \mathrm{E}$ & $\mathrm{N} / \mathrm{E}$ \\
\hline Tetracycline & $<1.9$ & 15.6 & N/E & $\mathrm{N} / \mathrm{E}$ & $\mathrm{N} / \mathrm{E}$ \\
\hline Trolox & $\mathrm{N} / \mathrm{E}$ & $\mathrm{N} / \mathrm{E}$ & N/E & $\mathrm{N} / \mathrm{E}$ & $566.08 \pm 13.81$ \\
\hline Gallic acid & $\mathrm{N} / \mathrm{E}$ & $\mathrm{N} / \mathrm{E}$ & $<312$ & $\mathrm{~N} / \mathrm{E}$ & $\mathrm{N} / \mathrm{E}$ \\
\hline Ascorbic acid & $\mathrm{N} / \mathrm{E}$ & $\mathrm{N} / \mathrm{E}$ & $\mathrm{N} / \mathrm{E}$ & 100 & $\mathrm{~N} / \mathrm{E}$ \\
\hline
\end{tabular}

Legend: N/A: no action; N/E: not evaluated. In each column the values with significant differences $(p<0.05)$ are indicated by different letters ${ }^{a, b, c}$.

\subsection{Nuclear Magnetic Resonance-NMR}

p-hydroxybenzoic acid compound (1) was obtained as a beige amorphous solid; UV (solvent) $\lambda \max 255 \mathrm{~nm}$; NMR of ${ }^{1} \mathrm{H}\left(\mathrm{MeOD}-d_{4}, 400 \mathrm{MHz}\right) \delta \mathrm{H} 7.87(2 \mathrm{H}, \mathrm{d}, J=8.8 \mathrm{~Hz}, \mathrm{H}-2$ and $\mathrm{H}-6), 6.87(2 \mathrm{H}, \mathrm{d}, J$ $=8.8 \mathrm{~Hz}, \mathrm{H}-3 \mathrm{e} \mathrm{H}-5) ; \mathrm{RMN}^{3} \mathrm{C}\left(\mathrm{MeOD}-d_{4}, 100 \mathrm{MHz}\right), \delta_{\mathrm{C}} 170.56(-\mathrm{COOH}), 163.38(\mathrm{C}-4), 133.1$ (C-2 e C-6), 123.2 (C-1), 116.1 (C-3 e C- 5). In the ${ }^{1} \mathrm{H}-\mathrm{NMR}$ spectrum, the presence of a pair of doublets with constant coupling constant of $8.8 \mathrm{~Hz}(7.87$ and 6.87), characteristic of the substituted $1-4$ aromatic rings, was observed [32]. 
The ${ }^{13} \mathrm{C}$-NMR spectrum shows five carbon signals where this profile, and the hydrogen signals, confirmed the suggestion of a substituted 1-4 aromatic compound. The signal at 170.56 ppm was attributed to the carbon of the carboxylic acid group, and the signal at 163.3 ppm was attributed to an oxygenated aromatic carbon (C-4). The groups' positions were confirmed by the analysis of the two-dimensional spectrum, in which the homonuclear correlation ${ }^{1} \mathrm{H}-{ }^{1} \mathrm{H}$ COSY showed us a single correlation between the signals 7.87 and 6.87. The heteronuclear correlation of ${ }^{1} \mathrm{H} \times{ }^{13} \mathrm{C}-\mathrm{HMBC}$ multiple bonds showed the correlations among signal at 7.87 (H-2 and H-6) and signals $170.56(-\mathrm{COOH}$, $\left.J^{3}\right), 163.38\left(\mathrm{C}-4, J^{3}\right) 116.11\left(\mathrm{C} 3\right.$ and $\left.\mathrm{C} 5, J^{2}\right)$ and correlations among signal $6.87(\mathrm{H}-3$ and $\mathrm{H}-5)$ and signals $163.38\left(\mathrm{C}-4, J^{2}\right)$ and $123.23\left(\mathrm{C}-1, J^{3}\right)$. Data analysis and comparison with the literature allowed the compound to be identified as $p$-hydroxybenzoic acid [33].

Quercetin 3-O- $\beta$-galactopyranose or hyperoside (compound 4) HMRS: ${ }^{1} \mathrm{H}-\mathrm{NMR}$ (DMSO- $d_{6}$, $400 \mathrm{MHz}): 3.29\left(1 \mathrm{H}, \mathrm{H}-5^{\prime \prime}\right), 3.34\left(1 \mathrm{H}, \mathrm{H}-4^{\prime \prime}\right), 3.36$ E $3.45\left(2 \mathrm{H}, \mathrm{H}-6^{\prime \prime}\right), 3.60\left(1 \mathrm{H}, \mathrm{H}-2^{\prime \prime}\right), 3.66\left(1 \mathrm{H}, \mathrm{H}-3^{\prime \prime}\right)$, $5.36\left(1 \mathrm{H},{\left.\mathrm{H}-1^{\prime \prime}\right)}^{\prime} 6.21(1 \mathrm{H}, \mathrm{H}-8), \mathrm{H}-6\right), 6.81(1 \mathrm{H}, \mathrm{d}, J=8.8 \mathrm{~Hz}, \mathrm{H}-5), 7.47\left(1 \mathrm{H}, \mathrm{H}-2^{\prime}\right), 7.59(1 \mathrm{H}, \mathrm{d}, J=$ $\left.8.8 \mathrm{~Hz}, \mathrm{H}-6^{\prime}\right), 12.64(1 \mathrm{H}, \mathrm{OH}-5)$. The structure of hyperoside was identified by analyzing key signals from $1 \mathrm{D}$ and 2D-NMR spectroscopic data and comparison with the literature. The ${ }^{1} \mathrm{H}-\mathrm{NMR}$ spectrum showed a characteristic $\delta_{\mathrm{H}} 12.64$ signal of a C-5 hydroxyl group chelated on a structural flavonol and singlets at $\delta_{\mathrm{H}} 6.21$ and 6.43 typical of the meta-substituted ring A. Distorred doublets at $\delta_{\mathrm{H}} 6.81$ and 7.59 with coupling constant at $8.8 \mathrm{~Hz}$ and a singlet at $\delta_{\mathrm{H}} 7.47$ were observed, suggesting the presence of a quercetin derivative. The anomeric hydrogen of unit sugar, $\delta_{\mathrm{H}} 5.37$, showed direct coupling $\left({ }^{1} \mathrm{H} \times\right.$ ${ }^{13} \mathrm{C}$ in HSQC experiment) among $\delta_{\mathrm{H}}$ signals 5.37 and 101.5 typical of the galactose structure and had its position based on literature data [34].

\subsection{Antimicrobial Activity of Isolated Compounds}

The antimicrobial activity of each compound [ $p$-hydroxybenzoic acid (1), proanthocyanidins (2) and (3), and hyperoside (4)] isolated from the most active fractions (F2 and F4) was tested against $S$. aureus strains, however the IN50 values obtained were higher than those obtained from the fractions. The proanthocyanidin (3) showed the lowest IN50 value against S. aureus UFPEDA 02 (IN50 $=62.5 \mu \mathrm{g} / \mathrm{mL}$, but it was not effective towards $S$. aureus UFPEDA 705 (IN50 > $500 \mu \mathrm{g} / \mathrm{mL}$ ). The hyperoside (4) exhibited IN50 values of $250 \mu \mathrm{g} / \mathrm{mL}$ and $62.5 \mu \mathrm{g} / \mathrm{mL}$ against $S$. aureus UFPEDA 02 and S. aureus UFPEDA 705, respectively. The other two compounds showed IN50 values $\geq 500 \mu \mathrm{g} / \mathrm{mL}$ (Table 1).

\subsection{Antioxidant Action of Isolated Compounds}

As the fractions F2 and F4 were the most active in DPPH assay, we also evaluated the activity of their purified compounds using DPPH, TAA, and FRAP methods. The $p$-hydroxybenzoic compound was not able to inhibit the DPPH radical, and proanthocyanidins were the most antioxidant components in the F2 fraction, with IC50 of $124.8 \pm 7 \mu \mathrm{g} / \mathrm{mL}$ and $178.4 \pm 5 \mu \mathrm{g} / \mathrm{mL}$ for proanthocyanidins (2) and (3), respectively. Proanthocyanidins were also more active in total antioxidant activity (TAA) with $60 \pm$ $3.3 \%$ (2) and $35 \pm 0.67 \%$ (3). On the other hand, the main component of the F4 fraction (hyperoside; compound (4) had an IC50 of $258 \pm 20 \mu \mathrm{g} / \mathrm{mL}$ in DPPH assay and a weak TAA (4.31 $\pm 0.81 \%)$. Finally, the compounds had similar results in FRAP method with values of $529.91 \pm 21.55 \mu \mathrm{g} \mathrm{FeSO} / / \mathrm{mg}_{\text {, }}$ $550.22 \pm 10.43 \mu \mathrm{g} \mathrm{FeSO} 4 / \mathrm{mg}$, and $552.62 \pm 5.23 \mu \mathrm{g} \mathrm{FeSO}_{4} / \mathrm{mg}$ for hyperoside (4) and proanthocyanidins (2) and (3), respectively (Table 1).

\section{Discussion}

In the present work, we reported the bioguided purification and identification of compounds present in the leaves of A. columbrina, a medicinal plant found in Brazil [12,13]. The bioguided approach was performed using the anti-S. aureus and antioxidant actions as markers. Previous reports obtained by our group showed the antimicrobial potential of hydroalcoholic extracts from leaves of $A$. columbrina, in special against $S$. aureus. In brief, these data indicated that the ethyl acetate extracts (obtained 
by liquid-liquid extraction or by Soxhlet) have higher activity towards Gram-positive bacteria, such as $S$. aureus $[35,36]$. In addition, antioxidant activity was chosen as marker due the involvement of oxidative stress in the pathogenesis of diverse clinical situations that include cancer, sepsis, diabetes and neurogenerative diseases [37-39].

S. aureus are found in the skin, nasal cavity, and mucosal surfaces of at least one-third of the human population, these organisms can cause infections in the skin, lungs, joints, blood and central nervous system [40-44]. In particular, S. aureus are prevalent in the hospital environment and associated with many cases of prolonged hospitalizations and deaths [41,42,45]. Several strains of this species have also acquired resistance to multiple drugs and hypervirulent profiles; these characteristics make the treatment options for $S$. aureus very limited $[46,47]$. These features make $S$. aureus is one of the most devastating pathogens and highlight the need to identify new effective compounds [48,49]. In this way, the search for active molecules with therapeutic potential is of great importance.

Based on the anti-S. aureus activity, two fractions were selected for purification, leading to four isolated compounds: $p$-hydroxybenzoic acid (1), two proanthocyanidins (2 and 3 ), and hyperoside (4). These compounds were also detected as major constituents in the hydroalcoholic extract (data not shown). Proanthocyanidins and p-hydroxybenzoic acid were the major components of the F2, whereas the hyperoside and other major quercetin derivatives were the main molecules found in F4. In addition, we observed that those fractions with the lowest levels of these compounds showed the higher IN50 values (F1 and F5 with IN50 values $>500 \mu \mathrm{g} / \mathrm{mL}$ ).

The hyperoside showed the higher antimicrobial potential (IN50 $\leq 250 \mu \mathrm{g} / \mathrm{mL}$ for both used strains) among the compounds obtained from leaves of $A$. columbrina. Similar results were recently reported by Ren et al. [50], which showed that hyperoside had a minimal bacteridal concentration (MIC) of $250 \mu \mathrm{g} / \mathrm{mL}$ against $S$. aureus ATCC 25923. Although hyperoside has been found as a component of some plants with antimicrobial and antioxidant activity [50-54], its mechanism of antimicrobial action of has not been reported yet. In our work, hyperoside showed the lowest in vitro antioxidant action among the tested compounds; however, this biomolecule has shown antioxidant properties in in vivo [55-57] and cell-based models [56,58,59]. The antioxidant activity of hyperoside is also highlighted by its anti-inflammatory effects as shown by several reports [54,60-62]. Other promising pharmacological properties include the treatment of cancer $[63,64]$, obesity [65], arthritis [61], and diabetes [66].

The other isolated biomolecule obtained from $A$. columbrina was $p$-hydroxybenzoic acid, which showed activity against $S$. aureus UFPEDA02; however, it did not show inhibitory action towards the DPPH radical. The weak antiradical activity of $p$-hydroxybenzoic acid was observed by other authors [67]. In contrast, this compound has been pointed as antimicrobial agent against $S$. aureus, Staphylococcus epidermis, Escherichia coli, Pseudomonas aeruginosa, and Salmonella typhimurium [33,68,69], an effect usually associated with its relative hydrophobicity [70]. The reported MIC values against S. aureus ranged from 3 to $926 \mu \mathrm{g} / \mathrm{mL}[33,69]$, these differences may be related to the strains used in each study and methods applied. $p$-Hydroxybenzoic acid is also reported to have potential for the treatment of diabetes [71,72], neurodegeneration [73], and inflammatory disorders [74,75].

The proanthocyanidins purified from A. colubrina showed activity only against the standard $S$. aureus strain, but they were not effective against the clinical isolates. However, some reports highlight the effectiveness of these class as inhibitors of $S$. aureus growth [76,77]. On the other hand, these proanthocyanidins from A. colubrina showed the highest antioxidant properties. These compounds are indicated as useful for treatment of various diseases related to oxidative stress such as inflammatory, neurodegenerative, and cardiovascular disorders [78-80].

\section{Conclusions}

The bioguided approach (based on antioxidant and antimicrobial actions) employed in this study resulted in the purification of four bioactive compounds leaves of A. colubrina: two proanthocyanidins, $p$-hydroxybenzoic, and hyperoside. These compounds have been described as potential alternatives 
for the treatment of several diseases, such as diabetes, arthritis, and other inflammatory disorders. Herein, hyperoside is the biomolecule with higher anti- $S$. aureus activity; however, the compounds showed lower activity than the semipurified fractions. These data suggest that the compounds should act in combination to provide bacterial inhibition. This work also showed that the proanthocyanidins exhibited the highest in vitro antioxidant activity among the molecules purified from A. colubrina.

Although these compounds have been described as potential antimicrobial agents, the action mechanisms involved in the inhibition of $S$. aureus still need to be addressed in another study. As these compounds exhibited antioxidant and antimicrobial actions, they anti-infective properties could also be examined in future researches. Taken together, these results highlight the potential of $A$. colubrina leaves as an alternative source of bioactive compounds of interest for the pharmaceutical, food, and cosmetic industries.

Author Contributions: Conceptualization, D.R.C.d.A., M.V.d.S. and M.T.d.S.C.; methodology, D.R.C.d.A., L.C.N.d.S., C.S.d.A.L., W.H., and M.V.d.S.; validation, D.R.C.d.A., H.d.S.A., T.D.d.S., and J.R.G.d.S.A.; formal analysis, D.R.C.d.A., L.C.N.d.S.; investigation, D.R.C.d.A., J.P.F.N., B.d.A.R., T.A.R., R.S.S., A.P.d.O., W.H., and T.D.d.S.; resources, M.V.d.S. and M.T.d.S.C.; data curation D.R.C.d.A., A.P.d.O., W.H., and T.D.d.S.; writing-original draft preparation, D.R.C.A and A.P.d.O.; writing-review and editing, W.H., L.C.N.d.S., R.S.S., and T.D.d.S.; visualization, D.R.C.d.A. and L.C.N.d.S.; supervision, M.V.d.S. and M.T.d.S.C.; project administration, M.T.d.S.C.; funding acquisition, M.T.d.S.C.

Funding: The authors are grateful to the financial support of the following Brazilian agencies; Conselho Nacional de Desenvolvimento Científico e Tecnológico (CNPq), Coordenação de Aperfeiçoamento de Pessoal de Nível Superior (CAPES), Fundação de Amparo à Ciência e Tecnologia de Pernambuco (FACEPE; AMD-0141-2.00/2016) and Fundação de Amparo à Pesquisa e ao Desenvolvimento Científico e Tecnológico do Maranhão (FAPEMA; BMEPP-02241/2018).

Conflicts of Interest: The authors declare no conflict of interest.

\section{References}

1. World Health Organization. WHO Traditional Medicine Strategy: 2014-2023; World Health Organization: Geneva, Switzerland, 2013.

2. Souza-Moreira, T.M.; Salgado, H.; Pietro, R.C. Brazil in the context of plants and derivates quality control. Rev. Bras. Farmacogn. 2010, 20, 435-440. [CrossRef]

3. Steinhoff, B. Pyrrolizidine alkaloid contamination in herbal medicinal products: Limits and occurrence. Food Chem. Toxicol. 2019, 130, 262-266. [CrossRef]

4. Wang, Z.; Wang, H.; Wang, H.; Li, Q.; Li, Y. Heavy metal pollution and potential health risks of commercially available Chinese herbal medicines. Sci. Total Environ. 2019, 653, 748-757. [CrossRef] [PubMed]

5. Ahn, K. The worldwide trend of using botanical drugs and strategies for developing global drugs. BMB Rep. 2017, 50, 111-116. [CrossRef] [PubMed]

6. Da Silva, D.P.B.; Florentino, I.F.; da Silva Moreira, L.K.; Brito, A.F.; Carvalho, V.V.; Rodrigues, M.F.; Vasconcelos, G.A.; Vaz, B.G.; Pereira-Junior, M.A.; Fernandes, K.F.; et al. Chemical characterization and pharmacological assessment of polysaccharide free, standardized cashew gum extract (Anacardium occidentale L.). J. Ethnopharmacol. 2018, 213, 395-402. [CrossRef] [PubMed]

7. Wang, L.; Shen, X.; Mi, L.; Jing, J.; Gai, S.; Liu, X.; Wang, Q.; Zhang, S. Simultaneous determinations of four major bioactive components in Acacia catechu (L.f.) Willd and Scutellaria baicalensis Georgi extracts by LC-MS/MS: Application to its herb-herb interactions based on pharmacokinetic, tissue distribution and excretion studies in rats. Phytomedicine 2019, 56, 64-73.

8. Chaban, M.F.; Karagianni, C.; Joray, M.B.; Toumpa, D.; Sola, C.; Crespo, M.I.; Palacios, S.M.; Athanassopoulos, C.M.; Carpinella, M.C. Antibacterial effects of extracts obtained from plants of Argentina: Bioguided isolation of compounds from the anti-infectious medicinal plant Lepechinia meyenii. J. Ethnopharmacol. 2019, 239, 111930. [CrossRef] [PubMed]

9. Gontijo, D.C.; Brandao, G.C.; Nascimento, M.; Oliveira, A.B. Antiplasmodial activity and cytotoxicity, isolation of active alkaloids, and dereplication of Xylopia sericea leaves ethanol extract by UPLC-DAD-ESI-MS/MS. J. Pharm. Pharm. 2019, 71, 260-269. [CrossRef] [PubMed] 
10. De Viana, M.L.; Giamminola, E.; Russo, R.; Ciaccio, M. Morphology and genetics of Anadenanthera colubrina var. cebil (Fabaceae) tree from salta (Northwestern Argentina). Rev. Biol. Trop. 2014, 62, 757-767. [CrossRef] [PubMed]

11. Barreto, H.M.; Coelho, K.M.; Ferreira, J.H.; Dos Santos, B.H.; de Abreu, A.P.; Coutinho, H.D.; da Silva, R.A.; de Sousa, T.O.; Cito, A.M.; Lopes, J.A. Enhancement of the antibiotic activity of aminoglycosides by extracts from Anadenanthera colubrine (Vell.) Brenan var. cebil against multi-drug resistant bacteria. Nat. Prod. Res. 2016, 30, 1289-1292. [CrossRef] [PubMed]

12. Monteiro, J.M.; de Almeida Cde, F.; de Albuquerque, U.P.; de Lucena, R.F.; Florentino, A.T.; de Oliveira, R.L. Use and traditional management of Anadenanthera colubrina (Vell.) Brenan in the semi-arid region of northeastern Brazil. J. Ethnobio. Ethnomed. 2006, 2, 6. [CrossRef] [PubMed]

13. De Albuquerque, U.P.; de Oliveira, R.F. Is the use-impact on native caatinga species in Brazil reduced by the high species richness of medicinal plants? J. Ethnopharmacol. 2007, 113, 156-170. [CrossRef] [PubMed]

14. Soldati, G.T.; de Albuquerque, U.P. A new application for the optimal foraging theory: The extraction of medicinal plants. Evid. Based Complement. Altern. Med. 2012, 2012, 364564. [CrossRef] [PubMed]

15. Lucena, R.F.; Albuquerque, U.P.; Monteiro, J.M.; Almeida Cde, F.; Florentino, A.T.; Ferraz, J.S. Useful plants of the semi-arid northeastern region of Brazil-A look at their conservation and sustainable use. Environ. Monit. Assess. 2007, 125, 281-290. [CrossRef] [PubMed]

16. Silva, D.R.; Rosalen, P.L.; Freires, I.A.; Sardi, J.C.O.; Lima, R.F.; Lazarini, J.G.; Costa, T.; Pereira, J.V.; Godoy, G.P.; Costa, E. Anadenanthera Colubrina vell Brenan: Anti-Candida and antibiofilm activities, toxicity and therapeutical action. Braz. Oral Res. 2019, 33, e023. [CrossRef] [PubMed]

17. Da Silva, L.C.; Sandes, J.M.; de Paiva, M.M.; de Araujo, J.M.; de Figueiredo, R.C.; da Silva, M.V.; Correia, M.T. Anti-Staphylococcus aureus action of three Caatinga fruits evaluated by electron microscopy. Nat. Prod. Res. 2013, 27, 1492-1496. [CrossRef] [PubMed]

18. Da Silva, L.C.; da Silva, C.A., Jr.; de Souza, R.M.; Jose Macedo, A.; da Silva, M.V.; dos Santos Correia, M.T. Comparative analysis of the antioxidant and DNA protection capacities of Anadenanthera colubrina, Libidibia ferrea and Pityrocarpa moniliformis fruits. Food Chem. Toxicol. 2011, 49, 2222-2228. [CrossRef] [PubMed]

19. Gomes de Melo, J.; de Sousa Araujo, T.A.; Thijan Nobre de Almeida e Castro, V.; Lyra de Vasconcelos Cabral, D.; do Desterro Rodrigues, M.; Carneiro do Nascimento, S.; Cavalcanti de Amorim, E.L.; de Albuquerque, U.P. Antiproliferative activity, antioxidant capacity and tannin content in plants of semi-arid northeastern Brazil. Molecules 2010, 15, 8534-8542. [CrossRef]

20. Damascena, N.P.; Souza, M.T.; Almeida, A.F.; Cunha, R.S.; Damascena, N.P.; Curvello, R.L.; Lima, A.C.; Almeida, E.C.; Santos, C.C.; Dias, A.S.; et al. Antioxidant and orofacial anti-nociceptive activities of the stem bark aqueous extract of Anadenanthera colubrina (Velloso) Brenan (Fabaceae). Nat. Prod. Res. 2014, 28, 753-756. [CrossRef]

21. Mota, G.S.; Sartori, C.J.; Miranda, I.; Quilho, T.; Mori, F.A.; Pereira, H. Bark anatomy, chemical composition and ethanol-water extract composition of Anadenanthera peregrina and Anadenanthera colubrina. PLoS ONE 2017, 12, e0189263. [CrossRef]

22. Pessoa, W.S.; Estevao, L.R.; Simoes, R.S.; Barros, M.E.; Mendonca Fde, S.; Baratella-Evencio, L.; Evencio-Neto, J. Effects of angico extract (Anadenanthera colubrina var. cebil) in cutaneous wound healing in rats. Acta Cir. Bras. 2012, 27, 655-670. [CrossRef] [PubMed]

23. Pessoa, W.S.; Estevao, L.R.; Simoes, R.S.; Mendonca Fde, S.; Evencio-Luz, L.; Baratella-Evencio, L.; Florencio-Silva, R.; Sa, F.B.; Evencio-Neto, J. Fibrogenesis and epithelial coating of skin wounds in rats treated with angico extract (Anadenanthera colubrina var. cebil). Acta Cir. Bras. 2015, 30, 353-358. [CrossRef] [PubMed]

24. Guarneire, G.J.; Cardoso Junior, O.; Marques Lima, N.; Aguilar Santos, E.; Aguiar Schulze, C.; Pereira Silva, W.; Pedro Oliveira Batista, J.; de Paula Carli, G.; Castro, S.B.; Alves, C.C.S.; et al. Effect of Anadenanthera colubrina protease inhibitors a Paulinos an inflammatory mediator. Nat. Prod. Res. 2019, 14, 1-6. [CrossRef] [PubMed]

25. Santos, J.S.; Marinho, R.R.; Ekundi-Valentim, E.; Rodrigues, L.; Yamamoto, M.H.; Teixeira, S.A.; Muscara, M.N.; Costa, S.K.; Thomazzi, S.M. Beneficial effects of Anadenanthera colubrina (Vell.) Brenan extract on the inflammatory and nociceptive responses in rodent models. J. Ethnopharmacol. 2013, 148, 218-222. [CrossRef] [PubMed] 
26. Lima Rde, F.; Alves, E.P.; Rosalen, P.L.; Ruiz, A.L.; Teixeira Duarte, M.C.; Goes, V.F.; de Medeiros, A.C.; Pereira, J.V.; Godoy, G.P.; Melo de Brito Costa, E.M. Antimicrobial and Antiproliferative Potential of Anadenanthera colubrina (Vell.) Brenan. Evid. Based Complement. Altern. Med. 2014, 2014, 802696.

27. Souza Dos Santos, B.; Bezerra Filho, C.M.; Alves do Nascimento Junior, J.A.; Brust, F.R.; Bezerra-Silva, P.C.; Lino da Rocha, S.K.; Krogfelt, K.A.; Maria do Amaral Ferraz Navarro, D.; Tereza Dos Santos Correia, M.; Napoleao, T.H.; et al. Anti-staphylococcal activity of Syagrus coronata essential oil: Biofilm eradication and in vivo action on Galleria mellonela infection model. Microb. Pathog. 2019, 131, 150-157. [PubMed]

28. Quave, C.L.; Plano, L.R.; Pantuso, T.; Bennett, B.C. Effects of extracts from Italian medicinal plants on planktonic growth, biofilm formation and adherence of methicillin-resistant Staphylococcus aureus. J. Ethnopharmacol. 2008, 118, 418-428. [CrossRef] [PubMed]

29. Blois, M.S. Antioxidant determinations by the use of a stable free radical. Nature 1958, 181, 1199. [CrossRef]

30. Prieto, P.; Pineda, M.; Aguilar, M. Spectrophotometric quantitation of antioxidant capacity through the formation of a phosphomolybdenum complex: Specific application to the determination of vitamin E. Anal. Biochem. 1999, 269, 337-341. [CrossRef] [PubMed]

31. Benzie, I.F.; Strain, J.J. The ferric reducing ability of plasma (FRAP) as a measure of antioxidant power: The FRAP assay. Anal. Biochem. 1996, 239, 70-76.

32. Silva, T.; Carvalho, M.; Braz-Filho, R. Estudo espectroscópico em elucidação estrutural de flavonoides de Solanum jabrense Agra \& Nee e S. paludosum Moric. Quim. NOVA 2009, 32, 1119-1128.

33. Cho, J.-Y.; Moon, J.-H.; Seong, K.-Y.; PARK, K.-H. Antimicrobial activity of 4-hydroxybenzoic acid and trans 4-hydroxycinnamic acid isolated and identified from rice hull. Biosci. Biotechnol. Biochem. 1998, 62, 2273-2276. [CrossRef] [PubMed]

34. Pereira, C.; Júnior, B.; Bomfim, C.; Kuster, R.M.; Simas, N.K.; Sakuragui, C.M.; Porzel, A.; Wessjohann, L. Flavonoids and a neolignan glucoside from Guarea macrophylla (Meliaceae). Química NOVA 2012, 35, 1123-1126. [CrossRef]

35. De Araújo, D.R.C.; da Silva, L.C.N.; Harand, W.; Fernandes, J.M.; da Cunha Soares, T.; Langassner, S.M.Z.; Giordani, R.B.; Ximenes, R.M.; da Silva, A.G.; da Silva, M.V. Effects of Rainfall on the Antimicrobial Activity and Secondary Metabolites Contents of Leaves and Fruits of Anadenanthera colubrina from Caatinga Area. Pharmacogn. J. 2017, 9, 435-440. [CrossRef]

36. Araújo, D.; Da Silva, L.C.N.; Da Silva, A.G.; Macedo, A.; Correia, M.; Da Silva, M. Comparative analysis of anti-Staphylococcus aureus action of leaves and fruits of Anadenanthera colubrina var. cebil (Griseb.) Altschul. Afr. J. Microbiol. Res 2014, 8, 2690-2696.

37. Bar-Or, D.; Carrick, M.M.; Mains, C.W.; Rael, L.T.; Slone, D.; Brody, E.N. Sepsis, oxidative stress, and hypoxia: Are there clues to better treatment? Redox Rep. 2015, 20, 193-197. [CrossRef]

38. Umeno, A.; Biju, V.; Yoshida, Y. In Vivo ROS production and use of oxidative stress-derived biomarkers to detect the onset of diseases such as Alzheimer's disease, Parkinson's disease, and diabetes. Free Radic. Res. 2017, 51, 413-427. [CrossRef]

39. Lin, Y.H. MicroRNA Networks Modulate Oxidative Stress in Cancer. Int. J. Mol. Sci. 2019, $20,4497$. [CrossRef]

40. Villanueva, M.; Garcia, B.; Valle, J.; Rapun, B.; Ruiz de Los Mozos, I.; Solano, C.; Marti, M.; Penades, J.R.; Toledo-Arana, A.; Lasa, I. Sensory deprivation in Staphylococcus aureus. Nat. Commun. 2018, 9, 523. [CrossRef]

41. Karakonstantis, S.; Kalemaki, D. Evaluation and management of Staphylococcus aureus bacteriuria: An updated review. Infection 2018, 46, 293-301. [CrossRef]

42. Oliveira, W.F.; Silva, P.M.S.; Silva, R.C.S.; Silva, G.M.M.; Machado, G.; Coelho, L.; Correia, M.T.S. Staphylococcus aureus and Staphylococcus epidermidis infections on implants. J. Hosp. Infect. 2018, 98, 111-117. [CrossRef] [PubMed]

43. Prabhoo, R.; Chaddha, R.; Iyer, R.; Mehra, A.; Ahdal, J.; Jain, R. Overview of methicillin resistant Staphylococcus aureus mediated bone and joint infections in India. Orthop. Rev. 2019, 11, 8070. [CrossRef] [PubMed]

44. Astley, R.; Miller, F.C.; Mursalin, M.H.; Coburn, P.S.; Callegan, M.C. An Eye on Staphylococcus aureus Toxins: Roles in Ocular Damage and Inflammation. Toxins 2019, 11, 356. [CrossRef] [PubMed]

45. Troeman, D.P.R.; Van Hout, D.; Kluytmans, J. Antimicrobial approaches in the prevention of Staphylococcus aureus infections: A review. J. Antimicrob. Chemother. 2019, 74, 281-294. [CrossRef] [PubMed] 
46. Assis, L.M.; Nedeljkovic, M.; Dessen, A. New strategies for targeting and treatment of multi-drug resistant Staphylococcus aureus. Drug Resist. Updates 2017, 31, 1-14. [CrossRef] [PubMed]

47. Monteiro, A.S.; Pinto, B.L.S.; Monteiro, J.M.; Ferreira, R.M.; Ribeiro, P.C.S.; Bando, S.Y.; Marques, S.G.; Silva, L.C.N.; Neto, W.R.N.; Ferreira, G.F.; et al. Phylogenetic and Molecular Profile of Staphylococcus aureus Isolated from Bloodstream Infections in Northeast Brazil. Microorganisms 2019, 7, 210. [CrossRef]

48. Rello, J.; Parisella, F.R.; Perez, A. Alternatives to antibiotics in an era of difficult-to-treat resistance: New insights. Expert Rev. Clin. Pharm. 2019, 12, 635-642. [CrossRef]

49. Diniz, R.C.; Soares, L.W.; Nascimento da Silva, L.C. Virtual Screening for the Development of New Effective Compounds Against Staphylococcus aureus. Curr. Med. Chem. 2018, 25, 5975-5985. [CrossRef]

50. Ren, G.; Xue, P.; Sun, X.; Zhao, G. Determination of the volatile and polyphenol constituents and the antimicrobial, antioxidant, and tyrosinase inhibitory activities of the bioactive compounds from the by-product of Rosa rugosa Thunb. var. plena Regal tea. BMC Complement. Altern. Med. 2018, 18, 307. [CrossRef]

51. Da Costa Cordeiro, B.M.P.; de Lima Santos, N.D.; Ferreira, M.R.A.; de Araujo, L.C.C.; Junior, A.R.C.; da Conceicao Santos, A.D.; de Oliveira, A.P.; da Silva, A.G.; da Silva Falcao, E.P.; Dos Santos Correia, M.T.; et al. Hexane extract from Spondias tuberosa (Anacardiaceae) leaves has antioxidant activity and is an anti-Candida agent by causing mitochondrial and lysosomal damages. BMC Complement. Altern. Med. 2018, 18, 284. [CrossRef]

52. Andriamadio, J.H.; Rasoanaivo, L.H.; Benedec, D.; Vlase, L.; Gheldiu, A.M.; Duma, M.; Toiu, A.; Raharisololalao, A.; Oniga, I. HPLC/MS analysis of polyphenols, antioxidant and antimicrobial activities of Artabotrys hildebrandtii O. Hffm. extracts. Nat. Prod. Res. 2015, 29, 2188-2196. [CrossRef] [PubMed]

53. Tadic, V.; Oliva, A.; Bozovic, M.; Cipolla, A.; De Angelis, M.; Vullo, V.; Garzoli, S.; Ragno, R. Chemical and Antimicrobial Analyses of Sideritis romana L. subsp. purpurea (Tal. ex Benth.) Heywood, an Endemic of the Western Balkan. Molecules 2017, 22, 1395. [CrossRef] [PubMed]

54. Soares, S.S.; Bekbolatova, E.; Cotrim, M.D.; Sakipova, Z.; Ibragimova, L.; Kukula-Koch, W.; Giorno, T.B.S.; Fernandes, P.D.; Fonseca, D.A.; Boylan, F. Chemistry and Pharmacology of the Kazakh Crataegus Almaatensis Pojark: An Asian Herbal Medicine. Antioxidants 2019, 8, 300. [CrossRef] [PubMed]

55. Shi, Y.; Qiu, X.; Dai, M.; Zhang, X.; Jin, G. Hyperoside Attenuates Hepatic Ischemia-Reperfusion Injury by Suppressing Oxidative Stress and Inhibiting Apoptosis in Rats. Transpl. Proc. 2019, 51, 2051-2059.

56. Zou, L.; Chen, S.; Li, L.; Wu, T. The protective effect of hyperoside on carbon tetrachloride-induced chronic liver fibrosis in mice via upregulation of Nrf2. Exp. Toxicol. Pathol. 2017, 69, 451-460. [CrossRef] [PubMed]

57. Wu, L.; Li, Q.; Liu, S.; An, X.; Huang, Z.; Zhang, B.; Yuan, Y.; Xing, C. Protective effect of hyperoside against renal ischemia-reperfusion injury via modulating mitochondrial fission, oxidative stress, and apoptosis. Free Radic. Res. 2019, 53, 727-736. [PubMed]

58. Wang, X.; Fan, G.; Wei, F.; Bu, Y.; Huang, W. Hyperoside protects rat ovarian granulosa cells against hydrogen peroxide-induced injury by sonic hedgehog signaling pathway. Chem. Biol. Interact. 2019, 310, 108759. [CrossRef]

59. Gao, Y.; Fang, L.; Wang, X.; Lan, R.; Wang, M.; Du, G.; Guan, W.; Liu, J.; Brennan, M.; Guo, H.; et al. Antioxidant Activity Evaluation of Dietary Flavonoid Hyperoside Using Saccharomyces Cerevisiae as a Model. Molecules 2019, 24, 788. [CrossRef]

60. Yang, L.; Shen, L.; Li, Y.; Li, Y.; Yu, S.; Wang, S. Hyperoside attenuates dextran sulfate sodium-induced colitis in mice possibly via activation of the Nrf2 signalling pathway. J. Inflamm. 2017, 14, 25. [CrossRef]

61. Jin, X.N.; Yan, E.Z.; Wang, H.M.; Sui, H.J.; Liu, Z.; Gao, W.; Jin, Y. Hyperoside exerts anti-inflammatory and anti-arthritic effects in LPS-stimulated human fibroblast-like synoviocytes in vitro and in mice with collagen-induced arthritis. Acta Pharm. Sin. 2016, 37, 674-686. [CrossRef]

62. Fan, H.H.; Zhu, L.B.; Li, T.; Zhu, H.; Wang, Y.N.; Ren, X.L.; Hu, B.L.; Huang, C.P.; Zhu, J.H.; Zhang, X. Hyperoside inhibits lipopolysaccharide-induced inflammatory responses in microglial cells via p38 and NFkappaB pathways. Int. Immunopharmacol. 2017, 50, 14-21.

63. Guo, W.; Yu, H.; Zhang, L.; Chen, X.; Liu, Y.; Wang, Y.; Zhang, Y. Effect of hyperoside on cervical cancer cells and transcriptome analysis of differentially expressed genes. Cancer Cell Int. 2019, 19, 235. [PubMed]

64. Li, Y.; Wang, Y.; Li, L.; Kong, R.; Pan, S.; Ji, L.; Liu, H.; Chen, H.; Sun, B. Hyperoside induces apoptosis and inhibits growth in pancreatic cancer via Bcl-2 family and NF-kappaB signaling pathway both in vitro and in vivo. Tumour Biol. 2016, 37, 7345-7355. [CrossRef] [PubMed] 
65. Berkoz, M. Effect of Hyperoside on the Inhibition of Adipogenesis in 3t3-L1 Adipocytes. Acta Endocrinol. 2019, 15, 165-172.

66. Zhang, Y.; Wang, M.; Dong, H.; Yu, X.; Zhang, J. Anti-hypoglycemic and hepatocyte-protective effects of hyperoside from Zanthoxylum bungeanum leaves in mice with high-carbohydrate/high-fat diet and alloxan-induced diabetes. Int. J. Mol. Med. 2018, 41,77-86. [CrossRef]

67. Sowa, A.; Zgorka, G.; Szykula, A.; Franiczek, R.; Zbikowska, B.; Gamian, A.; Sroka, Z. Analysis of Polyphenolic Compounds in Extracts from Leaves of Some Malus domestica Cultivars: Antiradical and Antimicrobial Analysis of These Extracts. BioMed Res. Int. 2016, 2016, 6705431. [CrossRef]

68. Mandal, S.M.; Dias, R.O.; Franco, O.L. Phenolic Compounds in Antimicrobial Therapy. J. Med. Food 2017, 20, 1031-1038.

69. Heleno, S.A.; Ferreira, I.C.; Esteves, A.P.; Ciric, A.; Glamoclija, J.; Martins, A.; Sokovic, M.; Queiroz, M.J. Antimicrobial and demelanizing activity of Ganoderma lucidum extract, p-hydroxybenzoic and cinnamic acids and their synthetic acetylated glucuronide methyl esters. Food Chem. Toxicol. 2013, 58, 95-100. [CrossRef]

70. Manuja, R.; Sachdeva, S.; Jain, A.; Chaudhary, J. A comprehensive review on biological activities of p-hydroxy benzoic acid and its derivatives. Int. J. Pharm. Sci. Rev. Res. 2013, 22, 109-115.

71. Peungvicha, P.; Thirawarapan, S.S.; Watanabe, H. Possible mechanism of hypoglycemic effect of 4-hydroxybenzoic acid, a constituent of Pandanus odorus root. Jpn. J. Pharm. 1998, 78, 395-398.

72. Franklin, Z.J.; McDonnell, B.; Montgomery, I.A.; Flatt, P.R.; Irwin, N. Dual modulation of GIP and glucagon action by the low molecular weight compound 4-hydroxybenzoic acid 2-bromobenzylidene hydrazide. Diabetes Obes. Metab. 2011, 13, 742-749. [CrossRef] [PubMed]

73. Winter, A.N.; Brenner, M.C.; Punessen, N.; Snodgrass, M.; Byars, C.; Arora, Y.; Linseman, D.A. Comparison of the Neuroprotective and Anti-Inflammatory Effects of the Anthocyanin Metabolites, Protocatechuic Acid and 4-Hydroxybenzoic Acid. Oxid. Med. Cell. Longev. 2017, 2017, 6297080. [CrossRef] [PubMed]

74. Yoo, S.R.; Jeong, S.J.; Lee, N.R.; Shin, H.K.; Seo, C.S. Simultaneous determination and anti-inflammatory effects of four phenolic compounds in Dendrobii Herba. Nat. Prod. Res. 2017, 31, 2923-2926. [CrossRef] [PubMed]

75. Khan, S.A.; Chatterjee, S.S.; Kumar, V. Low dose aspirin like analgesic and anti-inflammatory activities of mono-hydroxybenzoic acids in stressed rodents. Life Sci. 2016, 148, 53-62. [CrossRef] [PubMed]

76. Jin, S.; Eerdunbayaer, A.D.; Kuroda, T.; Zhang, G.; Hatano, T.; Chen, G. Polyphenolic constituents of Cynomorium songaricum Rupr. and antibacterial effect of polymeric proanthocyanidin on methicillin-resistant Staphylococcus aureus. J. Agric. Food Chem. 2012, 60, 7297-7305. [CrossRef] [PubMed]

77. Li, X.; He, C.; Song, L.; Li, T.; Cui, S.; Zhang, L.; Jia, Y. Antimicrobial activity and mechanism of Larch bark procyanidins against Staphylococcus aureus. Acta Biochim. Biophys. Sin. 2017, 49, 1058-1066. [CrossRef] [PubMed]

78. Yang, L.; Xian, D.; Xiong, X.; Lai, R.; Song, J.; Zhong, J. Proanthocyanidins against Oxidative Stress: From Molecular Mechanisms to Clinical Applications. Biomed. Res. Int. 2018, 2018, 8584136. [CrossRef]

79. Cheng, X.; Yang, S.; Xu, C.; Li, L.; Zhang, Y.; Guo, Y.; Zhang, C.; Li, P.; Long, M.; He, J. Proanthocyanidins Protect against beta-Hydroxybutyrate-Induced Oxidative Damage in Bovine Endometrial Cells. Molecules 2019, 24, 400. [CrossRef]

80. Gonzalez-Quilen, C.; Gil-Cardoso, K.; Gines, I.; Beltran-Debon, R.; Pinent, M.; Ardevol, A.; Terra, X.; Blay, M.T. Grape-Seed Proanthocyanidins are Able to Reverse Intestinal Dysfunction and Metabolic Endotoxemia Induced by a Cafeteria Diet in Wistar Rats. Nutrients 2019, 11, 979. [CrossRef]

(C) 2019 by the authors. Licensee MDPI, Basel, Switzerland. This article is an open access article distributed under the terms and conditions of the Creative Commons Attribution (CC BY) license (http://creativecommons.org/licenses/by/4.0/). 